\title{
Employability of young managers: a question of merit or aristocracy?
}

\author{
Ana Heloisa da Costa Lemos ${ }^{\dagger}$ \\ Pontifical Catholic University of Rio de Janeiro - PUCRIO \\ Veranise Jacubowski Correia Dubeux ${ }^{\Omega}$ \\ School of Advertising and Marketing and Researcher - ESPM \\ Mario Couto Soares Pinto \\ Getulio Vargas Foundation - FGV
}

SYNOPSIS: The article aims to discuss the relevance of two assumptions about the impact of education on the employability of degree holders: the study of Bourdieu (1988), who questions the relationship between vocational training and integration into the labor market and the human capital theory (SCHULTZ, 1967), which postulates that education increases productivity and employability of individuals. To achieve this goal we carried out a survey to map the employability of trainees in administration at a university in Rio de Janeiro. Students of this institution have different economic backgrounds, which allowed a comparison of their economic position and their access to professional opportunities. Taking in account the graduates' current conditions of employability, separating them in groups according to their origin, it was not possible to identify differences in the quality of jobs obtained, for both individuals from more privileged families and those less favored, endorsing Schultz's assumption about the importance of education.

Keywords: Employability; skills training; human capital theory; social stratification.

Recebido em 01/30/2010; revisado em 07/14/2010; aceito em 07/27/2010; available in 02/04/2011

Correspondência autores*:

${ }^{\dagger} \mathrm{PhD}$ in Sociology from the University Research Institute of Rio de Janeiro IUPERJ

Link: Puc - Rio

Address: Rua Marques de São

Vivente, 225 - Prédio do IAG. Gávea -

Rio de Janeiro - RJ - Brazil

CEP: 22451-900.

E-mail: aheloisa@ iag.puc-rio.br

Telephone: (21) 2138-9320
${ }^{\Omega} \mathrm{PhD}$ in Mechanical Engineering by the UFRJ

Link: School of Advertising and Marketing and Researcher ESPM -

Rio

Address: Rua Marques de São

Vicente, 225 - Prédio do IAG. Gávea

- Rio de Janeiro - RJ - Brazil

CEP: 22451- 900.

E-mail: vdubeux@espm.br

Telephone: (21) 2138-9320
${ }^{¥}$ Doctor of Business Administration of the PUCRio

Link: Superintendent of Management at the FGV

Address: Praia de Botafogo, 190, 10 andar -

Rio de Janeiro - RJ - Brazil

CEP. 22250-900

E-mail: mariocspinto@uol.com.br

Telephone: (21) 3799-9750

Nota do Editor: Esse artigo foi aceito por Antonio Lopo Martinez.

This work is licensed under a Creative Commons Attribution-Noncommercial-Share Alike 3.0 Unported License93 


\section{INTRODUCTION}

The debate about the ongoing transformations in the world of work has been characterized on the one hand, by the discourse that emphasizes the achievement of employability, presented as the main alternative for those who want to ensure their inclusion in the competitive labor market, and secondly by critical perspectives to this same speech, which sometimes denounce ideological content, and sometimes question the objective possibility of increasing employability to ensure that inclusion.

The discourse that values employability emphasizes the improvement of professional qualification as an important resource to be deployed by professionals who intend to enter the job market. The importance that vocational training acquires in this new context, signaled the revival of the main assumption underlying the theory of human capital (SCHULTZ, 1967): the belief in education as a strategic factor in increasing the productivity and competitiveness of individuals. The appreciation of professional qualification, understood as a requirement of employability leads to the resumption of the discourse that emphasizes the economic role of education, central to the work of Schultz, although this resumption occurs on a different basis compared to the one fashionable in the 1960s when it was associated to the economic growth and social integration of individuals. In the present context, education assumes a new role, no more being called to promote economic development, as called by the theory of human capital, but to increase the individual chances of entering the labor market, in a scenario in which the jobs become increasingly scarce. (CASTEL, 1998; RIFKIN, 2004).

But the enhancement of professional skills and, by extension, of education is not a consensus: the criticisms of this perspective come from authors who focus their analysis directly on the assumptions of the theory of human capital (RODRIGUES, 1997; MACHADO, 1998; GENTILI, 1999; FRIGOTTO 2001a; CARDOSO, 2000), as well as from theorists who, without considering these assumptions, end up questioning the assumptions mentioned by the nature of their investigations. In this sense, the work of Bourdieu (1988) about the structural conditions that reproduce the positions of class in capitalist society, held in France in the seventies decade of the last century, also serves as a counterpoint to the approach that sees education as the guarantor of the qualified insertion of individuals in the labor market. In "The Distinction" (1988), Bourdieu discusses the social stratification of contemporary society and discusses the social mechanisms that reproduce this stratification. In noting that the chances of those born within society's socio-cultural elites of remaining in this condition in adult life, are as great as the chances of children of disadvantaged of 
replicating the living conditions of their parents in the future, Bourdieu emphasizes the structural dimension of social inclusion, which relegates to the background the possibility of individual efforts, expressed largely by the expansion of the cultural capital, breaking class boundaries.

The tension between the premise of human capital theory, which considers qualification the key requirement in getting quality jobs, and Bourdieu's analysis about the obstacles faced by the disadvantaged to break with the structural constraints of their social insertion inspired this work. This tension led to the questioning about the impact of qualification expressed in obtaining a university education, on the employability of individuals. We sought through quantitative research to evaluate both the possibility of qualifications - expressed in obtaining a college degree - of effectively being a decisive factor for obtaining employment / work and the possible impact of elements such as social source and the network of relationships on individuals' employability.

Aiming to outline answers to these questions we conducted in November 2008, a survey to investigate the conditions of entry into the work market of students graduating in Business Administration from a Private University, of Rio de Janeiro. We surveyed undergraduating students who were concluding their education in that University, in 2008, to obtain information that might relate the conditions of participation of these individuals in the labor market with his/her socio-economic profile in order to discuss the extent to which Schultz and Bourdieu's theses are reflected in the sample. Since all respondents were completing their training in a prestigious University, we sought to investigate a possible link between the original economic strata of these individuals and the characteristics of their internship or job, considering for this analysis, the type of company and remuneration. It was understood that the convergence of indicators of higher quality job and privileged socio-economic origin on one hand, and lower quality job and less privileged socio-economic origin on the other hand, in a sample of individuals with the same professional training, could be construed as an endorsement of Bourdieu's thesis, about the tendency to reproduce social inequalities. Moreover, the absence of such convergence would strengthen Schultz's argument about the importance of education as an investment able to improve the competitiveness of individuals. The possibility of confirmation of this second situation could be an indicator of the positive impact of education on the social and professional life of their holders, regardless of their social origin and networking. Without 
attempting to provide definitive evidence to the questions, this study sought to explore the relationships proposed

\section{THEORETICAL FRAMEWORK}

\subsection{Employability and the resumption of the human capital theory}

Valued by some and criticized by others, the employability category is present in the contemporary debate on unemployment and productive restructuring. The discourse that emphasizes the achievement of employability underscores the importance of investments in the skills of the workforce as a resource to make it better able to get jobs with better quality and pay. This signals the resumption of assumptions of the human capital theory, developed by Schultz (1967) in the 1960s in order to explain the difference in economic development among capitalist nations.

The author's fundamental proposition is that, through investment in education, people value their abilities and they have influence on the patterns of accumulation of savings and capital formation, in addition to altering the structure of payments and salaries. In simple terms, education is seen as an investment that increases productivity and profits for workers, and boosts economic development.

The perception that education is an investment and that the productive capacity of work is largely a means of production, reinforces the concern about the qualifications of the worker, which is understood as an exponentiation factor of economic growth and individual chances to access the best jobs. The education capital accumulated by the employee not only ensures his/her increased productivity, as it explains the individual differences of opportunities for insertion in the market and of remuneration received.

Criticized by Marxist-oriented approaches (GENTILI, 1999, 2001; FRIGOTTO, 2001a, 2001b), this theory came to lose part of its appeal in the 1970s and 1980s, but without losing effectiveness. However, since the late 1980s, the effect of productive restructuring in the number of available jobs has given fresh impetus to that theory. After a period of relative obscurity, the human capital theory came to occupy central place in discussions on unemployment, quality of jobs and economic growth. This resumption adds new meaning to resumes to the debate on the impact of education on the lives of individuals and nations, keeping, however, the kernel of the argument that human capital is the main driver of economic development. 
The enhancement of professional training of the workforce as a vector for improving economic conditions, either nationally or individually, is echoed in recent work by economists such as Menezes-Filho (2006, 2007, 2008), Fernandes and Menezes-Filho (2002), Souza (2007), Ferreira (2000), Soares \& Gonzaga (1997), Camargo and Almeida (1994), among others, who support the thesis that the contemporary crisis of unemployment requires investment in professional training.

Camargo and Almeida (1994), analyzing the correlation between investment in human capital and poverty, and Soares \& Gonzaga (1997), in a study on the influence of education in wage determination of the Brazilian labor force, rely on the human capital theory, in attributing the wage gap of workers to their instruction capital. Not coincidentally, one of the results of this work was the design of a qualification-earning segmentation model in order to discuss the importance of policies aimed at enhancing the work force as a means of reducing income inequality in Brazil. In this model, a test was performed mapping the salaries of workers in Brazil vis-a-vis their qualification, in order to verify the hypothesis of duality of the Brazilian labor market, in which, possibly, different levels of qualification would be associated with different salaries. Since the conclusion of the study points to the absence of duality in the Brazilian labor market, the authors said that "... education is a basic determinant of wages and access to good jobs in Brazil. (SOARES AND GONZAGA, 1997:3). According to the authors, the lack of basic qualifications for a significant proportion of the workforce in developing countries justifies the investment in education since it would generate gains in wages, productivity and, ultimately, social mobility.

Also in Ferreira (2000) one can find a similar idea. His study pointed to a causal relationship between educational gaps and differences in income among Brazilian workers. We must mention that this work did not take into consideration factors targeting sector, geography or gender in its premises, which can generate questions about their results. Anyway, for the author, "the empirical evidence strongly suggests that education remains the most powerful variable for explaining Brazilian inequality" (FERREIRA, 2000:24).

The relationship between the workers' level of education and income from wages is also the subject of research by Menezes-Filho (2006) that aims to examine the impact of the educational composition of the workforce and return to school on the dispersion of wages of male workers. Although the study revealed that, during the study period (1977-1997), improvement in the overall educational level of the workforce did not reduce the inequality between the wages earned, a projection made by the author for the next 40 years (from 1997 
on) indicates that there is a tendency of inequality reduction, for the next decades, reflecting the positive impact that the increase in schooling tends to produce in the medium term, for all workers. In a later work, Tavares and Menezes-Filho (2008) found similar results, which, on one hand show that increasing the educational level of workers has not produced effects in terms of reduced income inequality, but on the other hand indicate that in next few years, this phenomenon tends to be reversed. Anyway, the large wage gap between workers observed by the author between workers with contrasting schooling are a reflection of the weight of education in the distribution of wage premiums in Brazil. Thus the higher the educational gap, the greater the difference in pay, which ultimately generates a large wage inequality while the average education level of the global population does not increase significantly, which tends to occur in coming decades, as indicated by the author's projections.

Conclusively, it can be postulated that the assumptions underlying the human capital theory support the enhancement that professional qualification has been receiving in Brazil in recent years. Pressured by fierce competition for jobs, individuals seek to invest increasing resources, aiming to improve their training, hoping to increase their employability. It is worth asking, however, whether this investment effectively ensures greater competitiveness to its holders, regardless of their social background, or if it results in a promise that presents itself unequally to its holders: real, for those who combine professional training with better attributes that refer to their socio-economic origin, or illusory, for those whose only difference is better quality training.

\subsection{Conditions for the reproduction of social inequalities}

By studying the social stratification of contemporary society, with reference to France of the nineteen seventies, Bourdieu (1988) emphasized the structural conditions that reproduce social inequalities. By mapping the different social strata starting from their greater or lesser possession of cultural and/or economic capital, the author expands the vision of the social stratification of capitalist society. According to Bourdieu, to understand the social dislocation of a particular individual, you must map his/her social origin. The result of his research questions the traditional understanding, based on the meritocratic ideology of capitalist societies in which social mobility is the result of individual effort. As indicators of the tendency to reproduce social inequalities, Bourdieu stresses that:

$41.7 \%$ of children of professionals and $38.9 \%$ of the children of engineers, superior or average administrative employees of businesses occupy administrative or general management jobs opposed to $25.7 \%$ overall. By contrast, $47.9 \%$ of children of skilled workers, and $43.8 \%$ of children of foremen and $41.1 \%$ of children of 
technicians staff technical, production, manufacture or maintenance functions compared to $29.7 \%$ overall. (Bourdieu, 1988:133).

This finding is linked to another on the remuneration received by these workers. According to the author:

... the senior employees coming from families of employees received in 1962 an average annual salary of 18,027 francs vis-a-vis 29,470 francs for the children of industrial or mass merchandisers; the engineers children of agricultural workers and self-employed farmers received 20,227 francs vis-a-vis 31,388 francs for the children of industrialists and large merchants. (Bourdieu, 1988:133).

With these and other research results, Bourdieu reinforces the notion that children of parents who hold? great economic or cultural capital?? tend to reproduce these heirlooms, the same way as the children of holders ? of smaller capital are less likely to increase their capital, either cultural or economic. Equally striking was the finding that there are social "vocations" (BOURDIEU, 1988), directing the children of the wealthier classes to the best jobs, the same that those from working class are channeled to positions of less visibility and/or remuneration. Thus, children of economic and cultural elites are mostly driven to university degree courses and to manage the family business while the children of unskilled workers are direct their professional aspirations to careers that require less skill, conditioning individual trajectories to trajectories of class, respecting a few exceptions. Such "vocations" more easily lead the children of people with diplomas of higher education to a similar education and, especially, having the power to boost the use of this degree by the holders of better social conditions when compared to children of less skilled workers, even when they reach such higher education level.

The author also emphasizes that the children of elites, besides being leaders in obtaining a diploma, are also suffer less the effects of devaluation of this training due to the popularization of higher education courses. The growing number of graduates (and even holders of high school diplomas), including those from economically and culturally less advantaged levels, tends to devalue this training, but this effect reaches much further in the second group than in the first. In France, Bourdieu attributes this effect to the social background of a diploma holder, because "the title is what its holder is economically and socially worth, whereby the yield of academic capital is a function of the economic and social capital which can be applied to its enhancement" (Bourdieu, 1988:133).

Besides the economic and cultural capital, Bourdieu also stresses the importance of social capital, "capital of worldly relationships that can, depending on the case, provide 'useful support', the capital of good repute and respectability that it is essential to attract or 
secure the confidence the good society" (BOURDIEU, 1988:118) This capital, combined with higher formal education, increases the chances of converting the graduate training received into economic capital. In other words, that asset opens doors to good jobs, good clientele, with good contacts that ultimately allow the children of the economic and/or cultural elite to reproduce their social status.

Without denying the importance of cultural capital as a source of condition of membership in the cultural and economic elites, to the extent that this asset can be converted into economic capital, Bourdieu's arguments allow to put the impact of formal higher education on the employability of its holder in relative terms, since this impact tends to be stronger for those who have conditions that combine different types of the capital mentioned. Thus, education would not be a resource that in principle extends the chances of social advancement of all its holders, since these would be derived from combinations of these assets with other types of capital. Therefore, a higher education in a reputed university, although it may open doors for undergraduates from lower classes, probably will not open the same doors that present themselves to those originating from the dominant classes. Moreover, the condition of holding more cultural capital - expressed in obtaining a college degree - is, according to the author, strongly conditioned by social origin, since the chances of children from economic and/or cultural elites in gaining these qualifications is significantly higher than the likelihood of those children who have little economic and cultural capital to reach that same goal.

Although the study by Bourdieu refers to French society in the nineteen-sixties and nineteen-seventies, his conclusions allow us to reflect on the contemporary Brazilian reality, since the positive impact of social capital and family background of the holder of a college degree on the professional and social insertion of this holder is far from being a strange fact in our social context.

\section{METHODOLOGICAL ASPECTS OF RESEARCH}

Aiming to explore the relevance of Bourdieu's considerations about the reproduction of social inequalities and of Schultz on the impact of education on the competitiveness of individuals, a survey to map the conditions of participation in the labor market for undergraduate business students, from a private University, who are in the final year of their programs was carried out. The option for a survey was due to the fact that the conceptual assumptions considered originating from a macro perspective, which led researchers to adopt a research strategy that allows making inferences about trends in a population (Creswell, 
2007). The purpose of this research was to contribute to a better understanding of the relationships between the employability of a group of individuals, their formal education and their social origin.

The main variables considered in the survey tried to identify the undergraduate's employment status, the company he/she works for, the earned salary, and the socio-economic profile, the latter delineated from questions relating to family income, neighborhood, school attended, parents' education and profession, and frequency of trips abroad. These variables were addressed through closed questions in the questionnaire developed by the researchers themselves.

The survey was conducted based on the questionnaire distributed to all undergraduates on the day of the presentation of the work completing their undergraduate course. The instrument was delivered by professors to the students, after a brief explanation of its purpose, and collected soon after completion. With this procedure we obtained a response of all undergraduates in Business of that University, in 2008, , totaling 115 individuals. As noted previously, the survey aimed to identify possible correlations between the respondents' quality of employment, his/her formal education and socio-economic origin.

Data were collected on printed questionnaires, stored in an Excel for Windows (Microsoft Corporation) database. The analysis and interpretation of data obtained in the descriptive phase of this research was made with the SPSS software v17 (Statistical Package for Social Science) for Windows, using the following statistical tools: analysis of data related to simple and cumulative frequency, average and standard deviation and statistical tests to demonstrate the difference of distribution of the sample means of the analyzed groups. With the purpose of comparing the statistical parameters (average salary of the study groups) related to the Bourdieu's assumption, we used the test of hypothesis called the comparison of means, allowing the statistical inference of these data (Kazmier, 2007).

The data generated in this process were analyzed considering, especially, Bourdieu's thesis on the structural conditions of reproduction of social inequalities. In the survey in question they would be manifest in the possible tendency of individuals with higher family incomes - privileged in the economic sphere - to have better quality jobs, in medium or large size companies and higher salaries than those of less endowed origin, notwithstanding both groups having the same higher education. It would appear that the possible confirmation of this trend would strengthen the relevance of Bourdieu's considerations to study the dynamics of entry into the work market of graduates of higher education in Brazil. Moreover, a possible 
rejection of the thesis of Bourdieu could be interpreted as a strengthening of the Schulz's assumptions Schultz about the importance of education.

\section{DISCUSSION OF RESULTS}

\subsection{The demarcation of subgroups of the analysis}

To begin the result analysis we tried to create filters able to identify subgroups within the sample of 115 respondents. Based on the questions raised by reading Bourdieu, explored in the previous section, the chosen filters refer to family income, condition (or not) of full scholarship at the university, frequency of trips abroad - because they are seen as indicators of the economic and cultural conditions of the individuals surveyed - as well as parents' education and graduates' language skills - indicative variables, according to Bourdieu, in terms of the cultural capital of their holders. The focus for these variables was intended to shape groups, which would on one side contain less economically privileged individuals within the analyzed group, and on the other side the most favored. The application of these filters allowed the identification of three groups containing, respectively, the "less privileged social origin" (Group A), "intermediaries" (Group B) and the "most favored social origin" (Group C), see Table 1. This categorization intended to address, above all, Bourdieu's considerations on the more or less favorable conditions that individuals have in transforming the cultural capital obtained through formal education into economic capital, which according to the author, varies depending on the economic and social origin of their holders. In light of these considerations, it was understood that the analysis would require the identification of the groups with the most socially contrasting situation.

Table 1: Distribution of gross monthly family income of all interviewees

\begin{tabular}{|c|c|c|c|c|}
\hline Gross monthly family income & Frequency & Percentage & Sub-groups & $\begin{array}{c}\text { Analyzed } \\
\text { groups }\end{array}$ \\
\hline Until $\mathrm{R} \$ 2,000.00$ & 6 & 5.2 & \multirow{2}{*}{$\begin{array}{l}\mathbf{1 7 \%} \\
(26-6 \text { individuals who do not } \\
\text { have a full scholarship }=20)\end{array}$} & \multirow{2}{*}{ Group A } \\
\hline Between $\mathrm{R} \$ 2,001.00$ and $\mathrm{R} \$ 5.000,00$ & 20 & 17.5 & & \\
\hline Between $\mathrm{R} \$ 5,001.00$ and $\mathrm{R} \$ 8.000,00$ & 16 & 13.9 & \multirow{3}{*}{$47.0 \%$} & \multirow{3}{*}{ Group B } \\
\hline Between $\mathrm{R} \$ 8,001,00$ and $\mathrm{R} \$ 12.000,00$ & 21 & 18.2 & & \\
\hline Between $\mathrm{R} \$ 12.001 .00$ and $\mathrm{R} \$ 16,000.00$ & 17 & 14.8 & & \\
\hline Above R\$ $16,001.00$ & 35 & 30.4 & $30.4 \%$ & Group C \\
\hline TOTAL & 115 & 100.0 & & \\
\hline
\end{tabular}

Source: Drafted by the authors.

The first group, called "Group A", contained the 20 that matched this condition with the condition of full scholarship (therefore $17 \%$ of all interviewees) out of the total of 26 individuals with income below $\mathrm{R} \$ 5,000.00$, as shown in Table 1. Of these twenty individuals, four (20\%) have household incomes of less than $\mathrm{R} \$ 2,000.00$ - a condition that 
puts them even less economically favored. Most members of this group (89\%) attended high school in public schools.

The intersection of these individuals' family income with the number of family members also allowed us to estimate a per capita income of $\mathrm{R} \$ 641.90$. With respect to language skills, a relevant indicator of the cultural capital of his/her holder, it was found that $20 \%$ do not consider themselves fluent in any language, $75 \%$ are fluent in English and only $5 \%$ are fluent in more than one language (Table 2). Another item indicative of the condition of the economic and cultural elite's condition was the frequency of trips abroad, proved to be of little significance for the group, since $85 \%$ had never traveled outside the country (Table $3)$.

Table 2: Language skills

\begin{tabular}{c|c|c}
\hline & Group A & Group C \\
\hline Languages & Percentage & Percentage \\
\hline None & $\mathbf{2 0 . 0}$ & $\mathbf{0 . 0}$ \\
One & $\mathbf{7 5 . 0} .9$ \\
Two & $\mathbf{5 . 0}$ & $\mathbf{3 4 . 3}$ \\
Three & $\mathbf{0 . 0}$ & $\mathbf{2 . 9}$ \\
\hline TOTAL & 100.0 & 100.0 \\
\hline
\end{tabular}

Source: Drafted by the authors.

Table 3 - Trips abroad

\begin{tabular}{c|c|c}
\hline \multirow{2}{*}{ Trips abroad } & Group A & Group C \\
\cline { 2 - 3 } & Percentage & Percentage \\
\hline Yes & $\mathbf{1 5 . 0}$ & $\mathbf{1 0 0 . 0}$ \\
No & $\mathbf{8 5 . 0}$ & 0.0 \\
\hline TOTAL & 100.0 & 100.0 \\
\hline
\end{tabular}

Source: Drafted by the authors.

The parents' education of the members of this group was also analyzed and compared with the parents of subjects in the "most favored", Group C (income above R \$ 16,000.00), as shown in Figure 1 because, according to Bourdieu, this would be a condition that identifies individuals as children (or not) of a cultural elite.

The appreciable difference between the educational level of parents of individuals in this group of parents and members of the group with higher family incomes rise reinforced the perception of less privilege in the first group. Although, even the group identified as disadvantaged, having a family income rather high for Brazilian standards - an inevitable bias of graduates in the a particularly well known HEI - it could be verified by examination of other variables, that this group included less socially favored individuals in the group of students. 


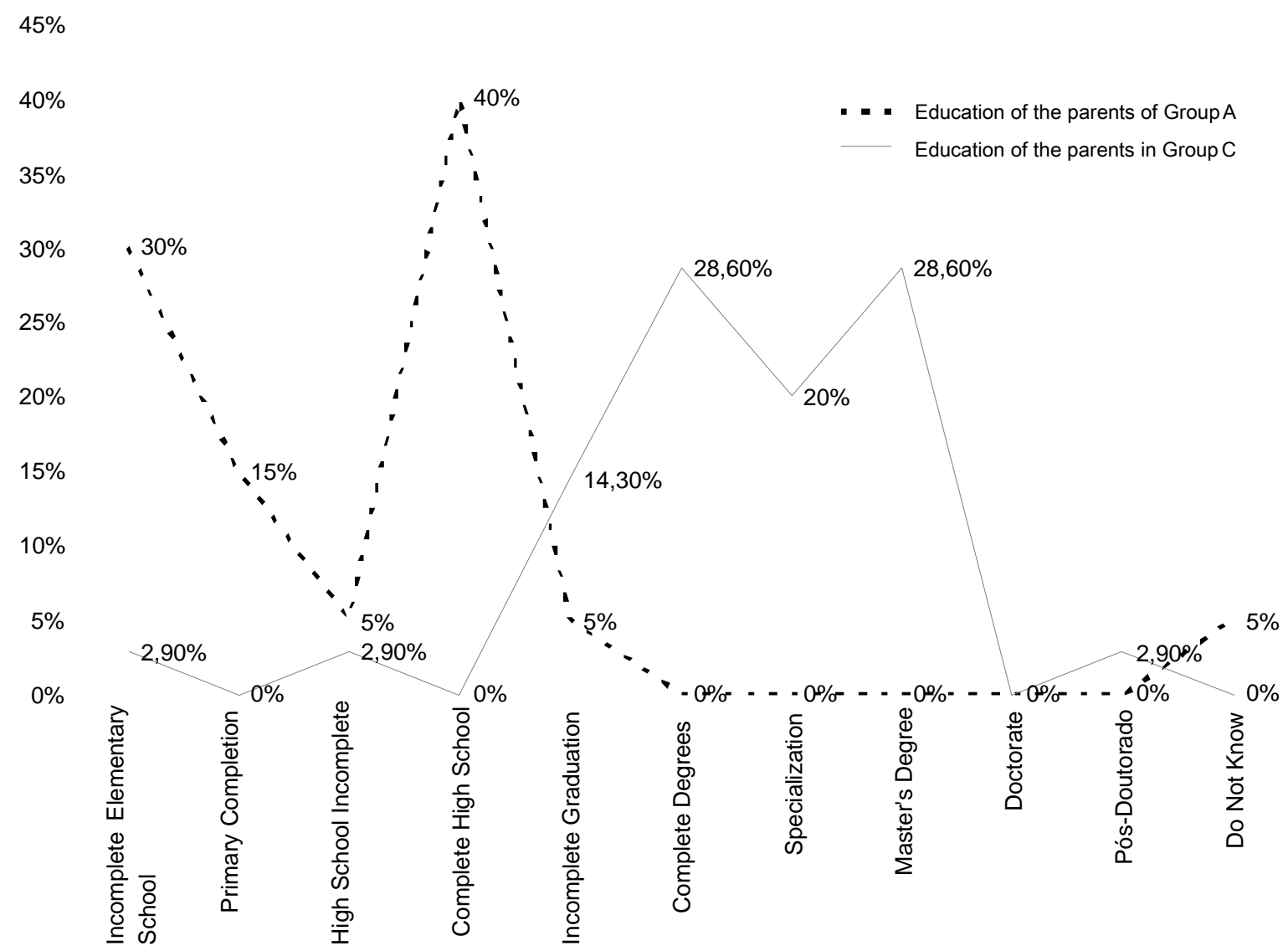

Figure 1: Education level of Parents Source: Drafted by the authors.

The second group (Group B) comprised individuals with monthly household income between $\mathrm{R} \$ 5,001.00$ and $\mathrm{R}$ \$ 16,000.00 (47\%). Although clearly more favored than the previous group with regard to economic status and having income that qualifies it as undoubtedly the economic elite in Brazil, for purposes of this analysis, it was not considered that the positions of greatest contrast between the first and third groups lend themselves better to the discussion guided by Bourdieu's considerations on the reproduction of social inequalities.

The third group, Group C, (30.4\%) gathered individuals with family income over R\$ $16,001,00$ which distinguishes its economic high class status. Such high income adds to other variables capable of confirm its privileged position in the economic sphere: all members studied only in private schools and none of them had scholarship. The education level of the parents of these graduates were considered as well to outline their privileged condition, as, according to Bourdieu, this is an important indicator of the cultural capital inherited by the 
children.It was found that, while in families with higher incomes, $80.1 \%$ of fathers had at least college, cases of post-graduate are not rare (51.5\% of all parents), while in lower incomes families there is not a single case of graduates among parents (Figure 1). It should also be noted also that about $45 \%$ of parents of respondents from lower income families have, at most elementary education, which contrasts with only $2.9 \%$ of the parents of the most favored, in this condition. These data would configure according to the author, a privileged condition for the descendants, since the children of the cultural elites tend to reproduce the "vocation" (BOURDIEU, 1988) of their parents' university careers. The mastery of foreign languages, another indicator of a privileged economic and cultural condition, especially English, appeared in $100 \%$ of the responses of group members. Apart from fluency in that language, $37 \%$ reported being fluent in at least one language (in most cases, Spanish), reinforcing its status as a cultural elite (Table 2). International travel - another key indicator of privileged origin - is part of the reality of these individuals, because all were at least once abroad and $66 \%$ said they regularly travel overseas on vacations (Table 3). The combination of these five variables identified these individuals as coming from economic and cultural elite.

\subsection{Key analytical considerations}

By investigating the conditions that lead to the reproduction of social inequalities, Bourdieu notes that the most advantaged tend to have more advantages to enforce the title received, expressed in obtaining quality jobs, based on their networks of relationships ( or their parents'), which constituted the so-called social capital. Based on this premise, one of the aspects analyzed in this research relates to how the respondents got theirjobs. When asked about the way they had access to the current job or internship, it was found that while only $11.8 \%$ of individuals with lower income (Group A) reported having obtained the job relying on information of acquaintances or family, those of higher income (Group C), counted with almost double the number of referrals by family and peers $(21.7 \%)$. The importance of social capital, as Bourdieu points out, increases the chances of the holders of cultural capital (in this case, education) can be converted into economic capital. Knowledge is a resource, an additional capital available to owners of greater economic capital, which gives its holders a better position than the group of economically disadvantaged to transform higher education into economic capital (Figure 2). The importance of the social network also appears, for the same groups, when considering the "referral by faculty colleague," only in this case, in a curious reversal: whereas $23.5 \%$ of the poor (Group A) were referred by colleagues only $8.7 \%$ of the more favored reported this condition (Group C). The weight of referrals by colleagues 
(23.5\%) in contrast to the less significant referraly by family (11.8\%) for the less favored, suggests that for these individuals, the social network built at the university level is relevant and compensates, at least in part, the lack of contacts outside the University, able to open doors to the world of work for them.

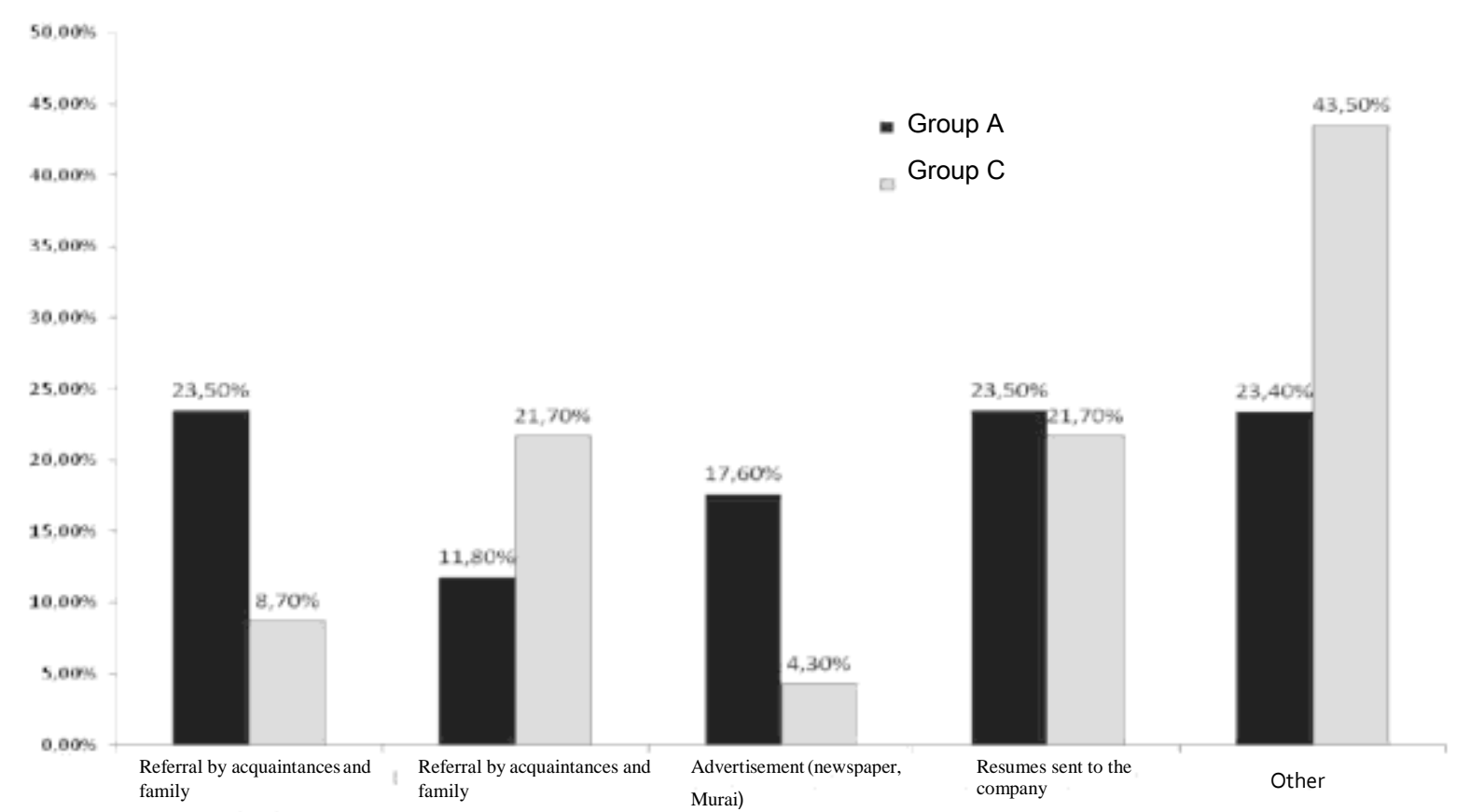

Figure 2: Chart with the percentage for the means of obtaining the information/contacts about job opportunities. Source: Drafted by the authors

Although relevant in light of the theoretical assumptions considered, the way in which to get a job is not an indicator able to explain alone the privileged status of the surveyed individuals. Getting a job - signaling the individual's attractiveness for the job market - and the quality of inclusion - as expressed by the nature of the employing organization and the remuneration received - are the key dimensions to be considered. Thus, we observed the graduates' insertion into the labor market, i.e. their employability. In the group identified as the least advantaged (Group A), we found that $90 \%$ of individuals were working at the time of the survey, which indicates an employment rate above the most favored group $(67.6 \%)$ and above the sample (115), since in analyzing the whole, it was noted that $81 \%$ of trainees were already employed (Figure 3). These results indicate a high rate of employability of the students of the HEI, on the eve of their graduation, as well as a particularly high rate among those with lower family income (Group A). Taken alone, these results seem to reinforce Schultz's about the potential of education as an exponentiation factor in their holders' 
competitiveness rather than Bourdieu's argument about the different values that cultural capital can take, depending on the holder's socio-economic origin. However, without an analysis of the quality of jobs obtained by the components of these groups, it would be premature to confirm this perception.

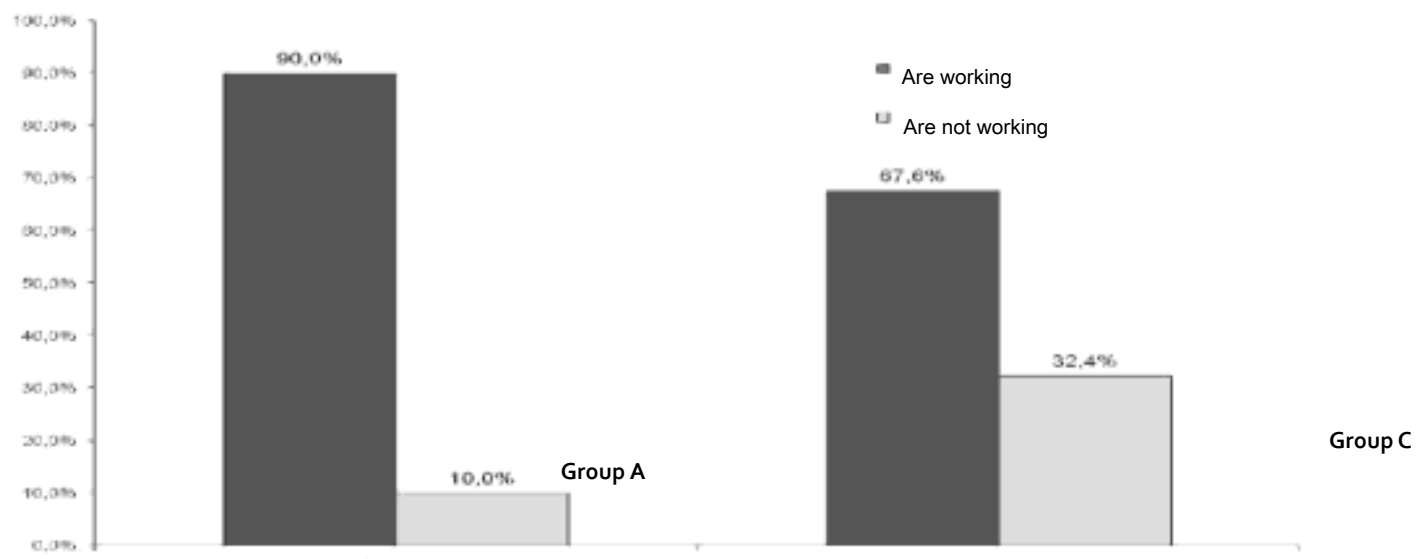

Figure 3: Employability condition by family income range Source: Drafted by the Authors.

Two aspects were considered in the investigation of the quality of workplaces obtained by the groups: company profile and the average remuneration earned by the groups. Considering that large companies are likely to pay more and offer more benefits and opportunities of professional growth, besides having more highly disputed selection processes, the quality of jobs or training in these companies would be a pertinent indicator of the quality of their staffs. Based on this assumption, the profile of the companies which hired individuals from the two groups was analyzed - emphasizing scale and area of operation with the conclusion that for the analyzed sample there were no significant differences related to the conditions of entry in the labor market between individuals with higher and lower incomes, according to the companies contacted. Both members of Group A and Group C got jobs in large multinational companies, traditionally the target of the graduates of top universities in the country. The distribution of individuals in both groups by smaller companies is also similar, which suggests that there are no distinctions between the insertion of individuals in these groups, when considering company and size.

Average earnings is another indicator of the quality of jobs considered can be seen in Chart 1 which consolidates information about the compensation received by members of groups $\mathrm{A}$ and $\mathrm{C}$. The distribution of the groups' remuneration and their standard deviation in the sample is also presented. It is noteworthy that there is a difference between the average 
pay of the two groups, namely Group $\mathrm{C}$ has an average salary 33\% higher than Group A. This difference should be qualified, however, because the standard deviation of Group C in the sample is $123 \%$ higher than that in Group A, indicating a wide dispersion between the salaries received, which makes this comparison between the averages inconclusive. By observing the individual frequencies in the $\mathrm{C}$ group, one realizes that two individuals, earning more than $\mathrm{R} \$ 4,001.00$ answer to a large in moving the group's average upwards. This finding led to performing an analysis based on statistical inference on the distribution of wage averages, since the earlier analysis, based only on calculations of point average, was limited.

\begin{tabular}{|l|c|c|}
\cline { 2 - 3 } \multicolumn{1}{c|}{} & Group A & Group C \\
\hline Remuneration of Respondents & Frequency (fi) & Frequency (fi) \\
\hline Until $\mathrm{R} \$ 1.000,00$ & 3 & 6 \\
\hline Between $\mathrm{R} \$ 1.001,00$ and $\mathrm{R} \$ 2.000,00$ & 11 & 7 \\
\hline Between $\mathrm{R} \$ 2.001,00$ and $\mathrm{R} \$ 3.000,00$ & 4 & 4 \\
\hline Between $\mathrm{R} 3.001,00$ and $\mathrm{R} \$ 4.000,00$ & 0 & 4 \\
\hline Between $\mathrm{R} \$ 4.001,00$ and $\mathrm{R} \$ 5.000,00$ & 0 & $\mathbf{1}$ \\
\hline Above $\$ 5.001,00$ & 0 & $\mathbf{1}$ \\
\hline Sample size & $\mathbf{1 8}$ & $\mathbf{2 3}$ \\
\hline Sample average & $\mathbf{R} \mathbf{1 , 5 5 5 . 5 6}$ & $\mathbf{R} \mathbf{2 0 6 5 . 2 2}$ \\
\hline Sample standard deviation $(\boldsymbol{S})$ & $\mathbf{R} \mathbf{6 2 1 . 1 3}$ & $\mathbf{R} \mathbf{1 , 3 7 7 . 6 5}$ \\
\hline
\end{tabular}

CHART 1: DISTRIBUTION OF AVERAGE REMUNERATION OF GROUPS A AND C

Source: Drafted by the authors.

The statistical inference on the distribution of the wage average tried to identify possible variations between the average pay received by members of Groups A and C. Bourdieu's considerations about the tendency to reproduce social inequalities have caused the formulation of hypotheses for the performance of the $t$ and $z$ tests, to identify possible differences between the salaries of the two groups. These hypotheses assume that the convergence of high salary and privileged socio-economic origin on one hand, and low pay and socio-economic and less privileged social origin on the other, in a sample of individuals with the same professional training, could be interpreted as a reinforcement of Bourdieu's theory, about the tendency of the reproduction of social inequalities, to the extent that salary advantage can be linked to social origin.

A test of the hypothesis test of the difference of the two sample means with a significance level of $5 \%$ was performed, with a margin of error $(\mathrm{E})$ of $2.5 \%$. The hypotheses tested were the following:

- $\quad$ Null hypothesis: the wage average of the population of individuals in Group A is equal to the one of subjects in Group $C\left(\mu_{\mathrm{A}}=\mu_{\mathrm{C}}\right)$ 
- Alternative Hypothesis: the wage average of the population of individuals in Group A is lower than the one of subjects in Group $C\left(\mu_{\mathrm{A}}<\mu_{\mathrm{C}}\right)$

One approach that can be used to decide whether or not to reject the null hypothesis is based on a probability called p-value (Chart 2). If we assume that the null hypothesis is true, $p$ is the probability of obtaining a sample result that is at least as improbable as the one observed, if the $\mathrm{p}$ value is less than the significance level $(\alpha)$, the null hypothesis can be rejected (Huff and Levine, 2000).

\begin{tabular}{|l|c|}
\hline \multicolumn{2}{|c|}{ Unilateral $t$ test: assuming a Normal distribution of the population } \\
\hline For $\mathrm{NC}=95 \%, \alpha$ will be $2.5 \%$ & Group A and C \\
\hline Difference of the sample average & $(\mathrm{R} \$ 509.66)$ \\
\hline $\mathrm{S}^{2}$ (pooled estimator of population variance) & $1,178,362.72$ \\
\hline $\mathrm{t}$ test & -1.49 \\
\hline Sample size of group A & $\left(\mathrm{n}_{\mathrm{A}}=18 \mathrm{n}_{\mathrm{C}}=23\right)$ \\
\hline Number of degrees of freedom( $\left.\mathrm{n}_{\mathrm{A}}+\mathrm{n}_{\mathrm{C}}-2\right)$ & 39 \\
\hline $\mathrm{t}$ Critical Value for the Distribution $($ critical $\mathrm{t})$ & -2.0227 \\
\hline $\mathrm{p}$ Value & Between $20 \%$ and $10 \%$ \\
\hline & Unilateral $\mathrm{z}$ test: considering that the sample is large enough to work with the $\mathrm{z}$ test \\
\hline For NC $=95 \%, \alpha$ will be $2.5 \%$ & -1.64 \\
\hline $\mathrm{z}$ Critical value of the normal distribution of probabilities (z-critical) & -1.58 \\
\hline $\mathrm{z}$ test & $5.71 \%$ \\
\hline $\mathrm{p}$ Value & \\
\hline
\end{tabular}

CHART 2: TESTING THE RESEARCH ASSUMPTIONS

Source: Drafted by the authors.

As the $p$-value of the $z$ and $t$ tests are greater than the significance level of $\alpha=0.5 \%$, the null hypothesis is not rejected, i.e. the wage average of the population of individuals in Group $\mathrm{A}$ is equal to the subjects of Group $\mathrm{C}(\mu \mathrm{A}=\mu \mathrm{C})$, invalidating the alternative hypothesis which assumes that advantage, in terms of pay, for those from economically disadvantaged families.

The results of this analysis can be interpreted as reinforcing Schultz's thesis about the impact of education in increasing their holders' productivity and competitiveness, in that it outlines, for the sample investigated, as an equalizer of the conditions of competition of their holders. The social differences identified between the two focus groups (A and C) did not stand out in the analysis of their conditions of participation in the labor market. Judging by the jobs obtained by graduates in the year investigated, there is no way to consider Bourdieu's claim that the more economically advantaged have better opportunities to enter the labor market as valid, since job quality differences indicative of the quality of the jobs did not stand out in the comparison between the two groups. On the contrary, there was an advantage in 
group A with respect to the employability item - understood as the ability to get a job because, as previously mentioned, $90 \%$ of its members were working at the time. However this advantage must be viewed with caution because the lower employability of the group of individuals with higher income may not be associated with a difficulty in obtaining employment, but to be a choice, due exactly to their privileged economic status. It is not uncommon for private university students to leave their jobs in the last semester to devote themselves to get a better final grade, but it is rare that a student coming from a low-income family would make this choice, because many times their salary is already higher than their parents'.

\section{CONCLUSIONS}

The absence of significant differences between the conditions of participation in the labor market of respondents with lower and higher incomes for the sample studied, allows us to develop an optimistic conclusion about the possibility of education is equalizing conditions of competition for quality jobs, whereby this conclusion is in line with both Schultz's thesis about the importance of education as a determinant of job opportunities and the remuneration received, as with recent studies by economists indicating the increased demand for skilled workers in Brazil (Fernandes e Menezes-Filho, 2002). The absence of significant differences between the conditions of participation in the labor market of the respondents with lower and higher income for the sample studied, which allows to develop an optimistic conclusion about the possibility of education is equalizing conditions of competition for jobs from quality, this conclusion in line with both Schultz's thesis about the importance of education as a determinant of insertion opportunities in employment and the remuneration received, as with recent studies by economists indicate that the increased demand for skilled workers in Brazil (Fernandes and Menezes-Filho, 2002). Evidence of this increased demand would help explain the fact that, regardless of social origin and the possible advantages this origin may represent, higher education is an important resource to his/her holder, valued by the labor market, which expresses this added value by remunerating their holders. Corroborating this conclusion, the fact that graduates object of the research, originate from an University considered a term of reference, reinforces the notion that (quality) education by increasing the value of the wage premium to his/her holder, creates objective conditions for their social climb.

The findings of this study may also contribute to increase the understanding of the relationship between specific university courses and market integration, because as emphasized by Bartalotti and Menezes-Filho (2007), in studying the relationship between the 
career performance in the labor market and the choice of profession by young people, there is a lack of studies that follow the choice of higher education by students and their trajectory in the labor market. According to the authors "there is a scarcity of databases that provide access to students' microdata, their performance and characteristics when choosing the course" (Bartalotti and Menezes-Filho, 2007 p: 10). This finding reinforces the interest of the study's authors to continue the annual collection of data concerning entry in the labor market of graduates and students from Business Administration courses, which will allow the development of historical data and more detailed tracking of this particular career.

Despite the positive results observed, these contrast of these results with recent work on the same theme (LEMOS DUBEUX and PINTO, 2008), requires balance in the optimism, because in that case, the results suggested the preeminence of Bourdieu's thesis about the reproduction of social inequalities. For the sample of students investigated in this research, the conditions of participation in the labor market were a little more favorable for individuals from families with higher economic capital. It is understood that the difference between the reported findings reinforce the importance of further research that can explore further, both the assumptions guiding the Schultz's work and Bourdieu's research. To achieve this goal, the construction of historical series is imperative. It is understood that the analysis of the set of results of consecutive surveys will better discern the relationship between education and social background, providing important support to the discussion of these factors' impact on their holders' employability and social mobility, a task on which the authors intend to devote the coming years. Notwithstanding the limitations of the study, it is believed that its findings may motivate other researchers to begin similar studies, drawing attention to the relationship between education, social origin and insertion in the labor market.

\section{REFERENCES}

BARTALOTTI, O.; MENEZES-FILHO, N. A. A Relação entre o desempenho da carreira no mercado de trabalho e as escolha profissional dos jovens. Revista de Economia Aplicada, v.11, p. 487-506, 2007.

BOURDIEU, P. La Distincion. Madrid: Taurus, 1988.

CARDOSO, A. M. Economia x Sociologia: eficiência ou democracia nas relações de trabalho? DADOS, Rio de Janeiro, v. 43, n. 1, p. 45-82, 2000.

CASTEL, R. As Metamorfoses da questão social: uma crônica do salariado. Petrópolis: Vozes, 1998. 
CAMARGO, J. M.; ALMEIDA, H. Human capital investment and poverty. Rio de Janeiro: PUC-Rio, 1994. (Texto para discussão, 319).

FERNANDES, R.; MENEZES-FILHO, N. A. Escolaridade e demanda relativa por trabalho: uma avaliação para o Brasil nas décadas de 80 e 90. In: CHAHAD, J. P.; MENEZES-FILHO, N. A. Mercado de trabalho no Brasil: salário, emprego e desemprego numa era de grandes mudanças. São Paulo: Ltr., 2002.

FERREIRA, F. Os Determinantes da desigualdade de renda no Brasil: luta de classes ou heterogeneidade educacional? Rio de Janeiro: PUC-Rio, 2000. (Texto para discussão, 415).

CRESWELL, J. W. Projeto de pesquisa: métodos qualitativo, quantitativo e misto. 2. ed. Porto Alegre: Artmed, 2007.

FRIGOTTO, G. Educação, crise do trabalho assalariado e do desenvolvimento: teorias em conflito. In: FRIGOTTO, Gaudêncio (Org.). Educação e crise do trabalho: perspectivas de final de século. Petrópolis: Vozes, 2001a.

Educação e formação humana: ajuste neoconservador e alternativa democrática. In: GENTILI, Pablo; SILVA, Thomaz (Orgs.). Neoliberalismo, qualidade total e educação. Petrópolis: Vozes, 2001b.

GENTILI, P. Educar para o desemprego: a desintegração da promessa integradora. In: FRIGOTTO, Gaudêncio (Org.). Educação e crise do trabalho: perspectivas de final de século. Petrópolis: Vozes, 2001.

O Conceito de empregabilidade. In: SEMINÁRIO NACIONAL SOBRE AVALIAÇÃO DO PLANFOR, 1999, São Carlos (SP). Anais... São Carlos: UNITRABALHO, 1999.

GIL, A. C. Métodos e técnicas de pesquisa social. 2. ed. São Paulo: Atlas, 1999.

KAZMIER, L. J. Estatística aplicada à economia e administração. 4. ed. São Paulo McGraw-Hill do Brasil, 2007.

LEMOS, A. H.C.; DUBEUX, V. J. C.; PINTO, M. C. S. Educação, empregabilidade e mobilidade social: convergencias e divergências. Cadernos EBAPE, Rio de Janeiro, v. 7, n. 2, p. 372-384, jun. 2009.

LEMOS, A. H. C.; PINTO, M. C. S. Empregabilidade dos administradores: quais os perfis profissionais que vêm sendo demandados pelas empresas? Cadernos EBAPE, v. 6, n. 4, p. 115, dez. 2008.

LEVINE, D. M.; BERENSON, M. L.; STEPHAN, D. Estatística: teoria e aplicações. Rio de Janeiro: LTC, 2000.

MACHADO, L. Educação básica, empregabilidade e competência. Trabalho e educação, Belo Horizonte, n. 3, p. 15-21, jan./jul. 1998. 
MENEZES-FILHO, N.A.; FERNANDES; R.; PICCHETTI, P. Rising human capital but constant inequality: the education composition effect in Brazil. Revista Brasileira de Economia, v. 60, n. 4, p. 407-424, oct./dec. 2006.

PINSONNEAULT, A.; KRAEMER, K. L. Survey research methodology in management information systems: in assessment. Journal of Management Information Systems, v. 10, n. 2, p. 75-105, Autumn 1993.

RIFKIN, J. O Fim dos empregos. São Paulo: M.Books, 2004.

RODRIGUES, J. Da Teoria do capital humano à empregabilidade: um ensaio sobre as crises do capital e a educação brasileira. Trabalho e Educação, Belo Horizonte, n.2, p. 215-230, ago./dez. 1997.

SCHULTZ, T. O Valor econômico da educação. Rio de Janeiro, Zahar, 1967.

Investindo no povo. Rio de Janeiro: Forense-Universitária, 1987.

SOARES, R. R.; GONZAGA, G. Determinação de salários no Brasil: dualidade ou nãolinearidade no retorno à educação? Rio de Janeiro: IPEA, 1997. (Texto para discussão, 38).

SOUZA, A. P. F.; SANTOS, A. T. L. A. Earnings inequality in Brazil: is it permanent or transitory? Revista de Econometria, v. 27, p. 261-286, 2007.

TAVARES, P.; MENEZES-FILHO, N. A. O Papel do capital humano na desigualdade de salários no Brasil entre 1981 e 2006. In: ENCONTRO DE ESTUDOS POPULACIONAIS, 16., 2008, Caxambú (MG). Anais... Caxambú: ABEP, 2008. 